\title{
Agricultural Biotechnology: Drawing on International Law to Promote Progress
}

J. Janewa OseiTutu

Florida International University College of Law, joseitut@fiu.edu

Follow this and additional works at: https://ecollections.law.fiu.edu/faculty_publications

Part of the Human Rights Law Commons, Intellectual Property Law Commons, and the International Law Commons

\section{Recommended Citation}

J. Janewa OseiTutu, Agricultural Biotechnology: Drawing on International Law to Promote Progress , 2015 Mich. St. L. Rev 531 (2015).

Available at: https://ecollections.law.fiu.edu/faculty_publications/130 


\title{
AGRICULTURAL BIOTECHNOLOGY: DRAWING ON INTERNATIONAL LAW TO PROMOTE PROGRESS
}

\author{
J. Janewa Osei-Tutu*
}

2015 MiCH. ST. L. REV. 531

\begin{abstract}
In Bowman v. Monsanto, the Supreme Court declined to apply the principle of exhaustion to limit the patentee's ability to control the reproduction of self-replicating inventions. This decision was justified from a patent law perspective on the basis that a patent holder has a right to prevent others from making the invention. But what happens when we take other perspectives into account? For instance, a farmer might have human rights or other rights that may need to be balanced against the patentee's right. Since globalized intellectual property standards were established through international agreements and much of the resistance to intellectual property laws is taking place at the international level, this Article turns to international law for guidance. Taking into consideration the competing regimes that touch on intellectual property rights, this Article concludes that we must continue to look for solutions within intellectual property law itself.
\end{abstract}

\section{TABLE OF CONTENTS}

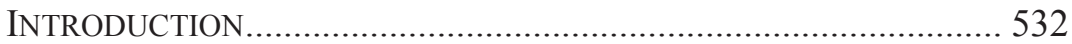

I. MONSANTO SUPREME COURT CASES.................................... 533

A. United States and Canada................................................. 533

B. Do Agricultural Technologies Present Unique Concerns?

II. TURNING TO INTERNATIONAL LAW ...................................... 540

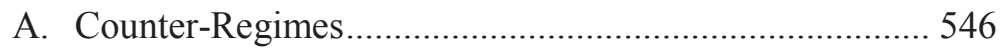

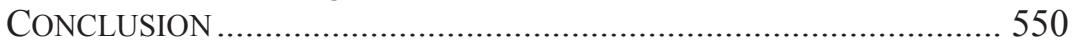

* Assistant Professor of Law, Florida International University College of Law; LL.M, McGill University, J.D. Queen's University, B.A. University of Toronto. I am grateful to Ryan Lavoie for his helpful research assistance and to the editors of the Michigan State Law Review for their excellent work. All errors and omissions are mine. 


\section{INTRODUCTION}

In 2013, the Supreme Court issued its decision in Bowman v. Monsanto, in which it concluded that patent law protects Monsanto's ability to control reproduction of its patented seed technology, even after the seed has been sold and used for planting by the farmer. But what happens when there are significant competing social considerations at stake? Although the topic of genetically modified food crops raises issues regarding intellectual property laws and biodiversity, this Article does not seek to address whether intellectual property laws have a positive or negative impact on crop biodiversity. ${ }^{1}$ Rather, the narrow focus of this Article is on the utility of "counter-regimes" in addressing concerns generated by the patenting of genetically modified foods.

This Article argues that it is helpful to look to international law for solutions, particularly since globalized intellectual property standards were established through international agreements. Furthermore, much of the resistance to harmonized intellectual property standards is taking place at the international level.

Ultimately, however, even if domestic courts were to take international law into account, there are no clear legal obligations that would have led to a different result. Part of that is due to the fact that the Monsanto cases do not present strong human rights claims. In addition, the other regimes are relatively weak as compared to the global intellectual property framework. While we can be guided by the various international instruments on intellectual property and the instruments on agricultural biodiversity, some part of the solution to the issues raised by the patenting of agricultural biotechnologies must come from within intellectual property law itself.

Part I will discuss the Monsanto cases from the United States and Canada as well as some of the reasons that we might be inclined to treat agricultural biotechnology differently from other kinds of technology. Part II will turn to the different international instruments that could be used to address some of the concerns regarding agricultural biotechnology.

1. See Jim Chen, Diversity and Deadlock: Transcending Conventional Wisdom on the Relationship Between Biological Diversity and Intellectual Property, 31 ENVTL. L. REP. 10625, 10626-27 (2001) (characterizing both sides of the debate between intellectual property and biodiversity as flawed). 


\section{Monsanto Supreme Court CASES}

\section{A. United States and Canada}

To what extent can the patentee control the use of subsequent generations of genetically modified seed? Although the facts were different, both the United States Supreme Court and the Canadian Supreme Court have confronted this issue in the past decade. The Canadian Supreme Court decision regarding Monsanto canola dates back to the 2002 case of Monsanto v. Schmeiser. The United States Supreme Court case, Bowman v. Monsanto, regarding Monsanto soybeans was issued approximately a decade later. The Bowman decision will be the primary focus of the discussion here, although the Schmeiser case will also be addressed.

Monsanto sells genetically modified soybean seeds to farmers under specific conditions. The soybean seeds are glyphosate resistant, which means that they will withstand the Roundup Ready herbicide when it is applied to them. ${ }^{2}$ The genetic modification that allows the seed to survive the application of the herbicide is passed down from one generation of seed to the next. ${ }^{3}$ When the farmer purchases the seeds, she agrees to use the seeds for only one year, but she cannot reuse the seeds for planting or sell the seeds to another person for planting. ${ }^{4}$ However, the farmer can consume the harvested soybeans or sell them to grain elevators, which then sell them for human or animal consumption. ${ }^{5}$

Mr. Bowman was a farmer based in Indiana. He purchased seed from Monsanto and complied with the contract the first year he purchased the seed. The following season, however, Mr. Bowman decided to purchase commodity seed from a grain elevator. This seed, which came from the harvest of other local farmers, was intended for human or animal consumption, but Mr. Bowman decided to plant it. ${ }^{6}$ When he sprayed the Roundup Ready herbicide on the plants, many of them survived because they contained the glyphosate-resistant gene. Mr. Bowman then saved the seed from the crop that survived for replanting the following year. Each year, he

2. Bowman v. Monsanto Co., 133 S. Ct. 1761, 1764 (2013).

3. Id. at 1764-65.

4. Id. at 1764 .

5. Id.

6. Id. at 1765 . 
repeated the same practice, sometimes adding soybean seeds purchased from the grain elevator. ${ }^{7}$

Monsanto sued Bowman for violating its patent by reproducing the seed without permission. ${ }^{8}$ The patentee has the exclusive right to make the patented article. ${ }^{9}$ Bowman argued that Monsanto's patent rights had been exhausted once the seed was sold. ${ }^{10}$ The doctrine of exhaustion provides that the patentee cannot control what happens with the patented article after the item has been sold. However, this does not give the purchaser of a patented invention the right to make new copies of the item. ${ }^{11}$

Bowman may not have been the most sympathetic plaintiff because he appears to have taken deliberate measures to avoid paying Monsanto for the glyphosate-resistant seed on an annual basis. ${ }^{12}$ However, one cannot judge the farmer too harshly given that the case presented the complex issue of how to treat self-replicating technologies. If the Court had accepted Bowman's argument that the patent right had been exhausted with the sale of the seed, his actions would have been perfectly legal. Moreover, as some interveners in this case have pointed out, even farmers who do not want to use Monsanto's genetically modified seeds may have their crops unintentionally mixed with the Monsanto product. ${ }^{13}$ Such farmers may also be infringing the Monsanto patent. In response to such concerns, Monsanto has promised that it will not litigate against

7. Id. ("Bowman saved seed from that crop to use in his late-season planting the next year-and then the next, and the next, until he had harvested eight crops in that way. Each year, that is, he planted saved seed from the year before (sometimes adding more soybeans bought from the grain elevator), sprayed his fields with glyphosate to kill weeds (and any non-resistant plants), and produced a new crop of glyphosate-resistant—i.e., Roundup Ready—soybeans.”).

8. Id.

9. 35 U.S.C. $§ 154(a)(1)$ (2012) ("Every patent shall contain a short title of the invention and a grant to the patentee, his heirs or assigns, of the right to exclude others from making, using, offering for sale, or selling the invention throughout the United States or importing the invention into the United States, and, if the invention is a process, of the right to exclude others from using, offering for sale or selling throughout the United States, or importing into the United States, products made by that process, referring to the specification for the particulars thereof.").

10. Bowman, 133 S. Ct. at 1765.

11. Id. at 1766 .

12. Id. at 1769 .

13. Brief of the Public Patent Foundation as Amicus Curiae in Support of Petitioner at 3, Bowman, 133 S. Ct. 1761 (No. 11-796) (arguing that the Federal Circuit decision would make farmers whose seeds were inadvertently contaminated infringers). 
innocent infringers. ${ }^{14}$ Other companies have made similar "patent pledges" or promises that they will not enforce their patent rights in certain instances. ${ }^{15}$ However, this can provide the user only limited comfort because, while users might be able to make an estoppel argument, the patentee may be well within its right to sue. ${ }^{16}$

Furthermore, as the Supreme Court of Canada case illustrates, even when it is not entirely clear how the farmer obtained the Monsanto seed, the courts may nonetheless favor the patentee. In 2004, the Supreme Court of Canada had an opportunity to decide what should happen when a farmer's seeds are mixed with genetically modified Monsanto seeds without the clear, deliberate actions seen in Bowman. In the Canadian case, Schmeiser $v$. Monsanto ${ }^{17}$ the plaintiff arguably had a more compelling case than Mr. Bowman. Nonetheless, Monsanto prevailed in the dispute. ${ }^{18}$

Percy Schmeiser was a commercial farmer in Saskatchewan. ${ }^{19}$ Although he had not purchased the Monsanto glyphosate-resistant seeds, tests revealed that his 1998 canola crop was comprised of more than 95\% Monsanto genetically modified canola. It was unclear how Schmeiser ended up with the genetically modified canola. ${ }^{20} \mathrm{~A}$ number of farmers near him had purchased the Monsanto product. ${ }^{21}$ By 2000 , nearly $40 \%$ of all canola grown in Canada was Monsanto glyphosate-resistant canola, so it was possible that his crops were inadvertently contaminated by Monsanto seed. ${ }^{22}$ However, the majority of the Court expressed the view that Schmeiser was not an innocent infringer because he had actively

14. See Monsanto's Commitment: Farmers and Patents, Monsanto, http://www.monsanto.com/newsviews/pages/commitment-farmers-patents.aspx (last visited Apr. 13, 2015) ("It has never been, nor will it be Monsanto policy to exercise its patent rights where trace amounts of our patented seed or traits are present in farmer's fields as a result of inadvertent means.").

15. See, e.g., Open Patent Non-Assertion Pledge, Google, http://www. google.com/patents/opnpledge/pledge/ (last visited Apr. 13, 2015); see also Dennis Crouch, Tesla Motors and the Rise of Non-ICT Patent Pledges, PATENTLY-O (June 16, 2014), http://patentlyo.com/patent/2014/06/motors-patent-pledges.html.

16. It has been suggested, however, that a "market reliance" theory could make such pledges legally enforceable. See Jorge L. Contreras, A Market Reliance Theory for FRAND Commitments and Other Patent Pledges, 2015 UTAH L. REV. (forthcoming).

17. Monsanto Canada Inc. v. Schmeiser, [2004] S.C.R. 902 (Can.).

18. Id. ๆ 97.

19. Id. 4 .

20. Id. 6 .

21. Id. 5 .

22. Id. $\uparrow 10$. 
collected and planted canola seeds that had survived the application of the Roundup Ready pesticide. ${ }^{23}$ The Court did not reach a conclusion on whether Schmeiser had "made" the patented gene contrary to Canadian patent law. ${ }^{24}$ However, the Court concluded that he had "used" the patented gene for commercial purposes, which amounted to an infringing use. ${ }^{25}$

Whether one agrees with these Monsanto decisions or not, the patent law analyses in both the United States and Canadian cases are supportable. Though it has been argued that the United States Supreme Court created an exception to patent exhaustion, ${ }^{26}$ the Court reasoned that the farmer made a new invention by reproducing the genetically modified soybean seed without Monsanto's permission. ${ }^{27}$ The Supreme Court refused to treat self-replicating technologies as distinct from other technologies and rejected what it called the "blame-the-bean defense" because Bowman was not a passive observer. ${ }^{28}$ Nonetheless, the Court left open the possibility that the result might have been different if Bowman had not taken deliberate steps to reproduce the glyphosate-resistant seed. The Court also stated that its decision was limited to the particular facts of this case and is not applicable to every case involving a self-replicating organism. $^{29}$
23. Id. ๆๆ 6, 28, 72 .
24. Id. ๆ 26-27 (internal quotation marks omitted).
25. Id. $₫$ Ф 69,72 .
26. Shubha Ghosh has said:

In its decision finding for Monsanto, the Federal Circuit creates an exception to the patent exhaustion doctrine for the sui-generis category of self-replicating technologies. The court repeated its reasoning in Monsanto v Scruggs that "[a]pplying the first sale doctrine to subsequent generations of self-replicating technology would eviscerate the rights of the patent holder." Effectively, the court has created an exception from the patent exhaustion doctrine for self-replicating technologies, meaning inventions that recreate themselves through reproduction.

Shubha Ghosh, Int'l Assoc. of Lawyers, Innovation, Health and the Right to Know: The Law of Food, Fiber and Toxins, Patents, GMO's, and Progress 4 (2014), available at http://www.google.com/url? sa=t\&rct=j\&q=\&esrc=s\&source= web\& $\mathrm{cd}=2 \&$ ved $=0 \mathrm{CCkQFjAB} \&$ url $=\mathrm{http} \% 3 \mathrm{~A} \% 2 \mathrm{~F} \% 2 \mathrm{Fwww}$.uianet.org $\% 2 \mathrm{Fsites} \% 2$ Fdefault $\% 2$ Ffiles $\% 2$ Fsafe_uploads $\% 2$ Fclients $\% 2$ F39144\%2Frapports $\% 2$ FGHOSH $\% 2520$ SHUBHA $\% 2520-\% 2520$ Innovation $\% 2520$ Health $\% 2520$ and $\% 2520$ the $\% 2520$ Right\%2520to\%2520Know\%2520140904.pdf\&ei=lU-WVI7UBoqYNpbTgdAP\& usg=AFQjCNFTQ8GcKP2Pz0Hc3RXJbeA4CZuDjw\&sig2=50_NdQzOxtFvbul6fx3jw.

27. Bowman v. Monsanto Co., 133 S. Ct.1761, 1765-66 (2013).

28. Id. at $1768-69$.

29. Id. at 1769 . 
Similarly, in the Schmeiser case, the Supreme Court of Canada emphasized that it was not addressing innocent infringers or any moral questions that may arise regarding agricultural biotechnologies. ${ }^{30}$ The Supreme Court of Canada noted that agricultural inventions "may give rise to concerns not raised in other fields - moral concerns about whether it is right to manipulate genes in order to obtain better weed control or higher yields. It is open to Parliament to consider these concerns and amend the Patent Act should it find them persuasive." 31

The question that follows is whether patent rights should be exhausted or otherwise limited when the technology concerns live, self-replicating organisms. ${ }^{32}$ This is distinct from the questions addressed by the United States Supreme Court in Bowman ${ }^{33}$ and the Canadian Supreme Court in Schmeiser. ${ }^{34}$ In Bowman, for instance, the United States Supreme Court expressed concern that the soybean seed could be reproduced an infinite number of times and that the patentee would not receive the benefit of the invention. ${ }^{35}$ The courts were focused on the benefit of the patent to which the patentee is entitled. Patent laws can help stimulate innovation, at least in industrialized countries. ${ }^{36}$ Accepting that innovators require some protection for their innovation, the next section of this Article will discuss whether there is something special about genetically modified self-replicating technologies that should distinguish them from other types of patented inventions.

30. Schmeiser, [2004] S.C.R. 902, ๆ 2 (“[W]e emphasize from the outset that we are not concerned here with the innocent discovery by farmers of 'blow-by' patented plants on their land or in their cultivated fields. Nor are we concerned with the scope of the respondents' patent or the wisdom and social utility of the genetic modification of genes and cells - a practice authorized by Parliament under the Patent Act and its regulations.").

31. Id. ๆ93.

32. Bowman, 133 S. Ct. at 1769.

33. "The question in this case is whether a farmer who buys patented seeds may reproduce them through planting and harvesting without the patent holder's permission. We hold that he may not." Id. at 1764.

34. Schmeiser, [2004] S.C.R. 902, Ф甲 1-2.

35. Bowman, 133 S. Ct. at 1766-67.

36. Brent B. Allred \& Walter G. Park, Patent Rights and Innovative Activity: Evidence from National and Firm-Level Data, 38 J. INT'L Bus. STUD. 878, 879-82 (2007). 


\section{B. Do Agricultural Technologies Present Unique Concerns?}

Different kinds of technologies may have a distinct impact on the users of the technology. In particular, patenting life forms and self-replicating organisms raises issues that are far more complex than anyone might have imagined when the first patent laws were enacted. Despite the fact that the Court in Diamond v. Chakrabarty famously concluded that "anything under the sun that is made by man" is patentable, ${ }^{37}$ patenting genes raises issues that are distinct from patenting machines. Patents relating to coffee lids, pens, or lawn mowers do not present the same difficulties as patents over self-replicating technologies like seeds or mice. Thus, while patent law may not distinguish between the different technologies, the effects of patents are felt more strongly in some areas of technology than others. This is not the same as resisting technology due to concern about a "parade of horribles," ${ }^{38}$ but rather, it is about recognizing that not all technologies present the same moral or ethical issues that may arise with technologies regarding plant, animal, or human genes.

This Article does not seek to engage in the debate about whether or not agricultural biotechnologies should be patented. But perhaps an argument can be made that there is something special about food or farming that warrants more than a narrow economic analysis of the interests of the patentee. ${ }^{39}$ Indeed, as James Chen

37. 447 U.S. 303, 309 (1980) (internal quotation marks omitted).

38. Id. at 316-17 ("The briefs present a gruesome parade of horribles. Scientists, among them Nobel laureates, are quoted suggesting that genetic research may pose a serious threat to the human race, or, at the very least, that the dangers are far too substantial to permit such research to proceed apace at this time. We are told that genetic research and related technological developments may spread pollution and disease, that it may result in a loss of genetic diversity, and that its practice may tend to depreciate the value of human life. . . . It is argued that this Court should weigh these potential hazards in considering whether respondent's invention is patentable subject matter under $\S 101$. We disagree.").

39. Saby Ghoshray, Food Safety and Security in the Monsanto Era: Peering Through the Lens of a Rights Paradigm Against an Onslaught of Corporate Domination, 65 ME. L. REv. 491, 492 (2013) (“Since our earliest ancestors' desire for a better hunting weapon to procure food or a better storage facility to avoid spoilage, food safety and security has shaped human social and technological evolution like no other essential element. The need to procure food has shaped our civilization since the first human graced our planet. Food continues to be a pivotal force in humankind's saga of life and death. Yet, despite stratospheric progress in scientific application surrounding food, food security and safety for all citizens continues to elude mankind."). 
explains, “"[c]opying'—often a deviant and difficult deed for wouldbe infringers of intellectual property in many other industries - is the very essence of agriculture. Whether cultivating plants or raising animals, farmers specialize in plying reproductive techniques and technology." ${ }^{40}$ If copying is the essence of what farmers do, then there is arguably some inherent tension between traditional farming practices and patenting self-replicating food crops.

This dialogue is about more than a particular company or product. It is about the future of food security at a time when food products are increasingly modified and possibly protected by intellectual property rights. ${ }^{41}$ Intellectual property law has been confronted with concerns about access to knowledge and access to medicines. ${ }^{42}$ What do intellectual property rights in genetically modified seeds or crops mean for access to food, if anything? There is some risk that agricultural biotechnology will create a dependency on IP-protected technologies over time, particularly as traditional farming practices and local knowledge are increasingly displaced by large-scale commercial food production. ${ }^{43}$ In the United States and Canadian context, it is the individual farmer pitted against the large agribusiness. In the broader global context, this becomes a question about the impact of intellectual property rights on the poor.

In isolation, patent law cannot provide satisfactory answers to complex issues of morality and the appropriate boundaries regarding intellectual property interests over seeds, plants, and animals. The Supreme Court clearly tells us that the patent right in the genetically

40. See Chen, supra note 1, at 10636 (arguing that Global South cannot criticize biotechnology industries of bio-piracy while supporting farmer's rights because farming practices are based on similar free-riding practices).

41. H. Charles J. Godfray et al., Food Security: The Challenge of Feeding 9 Billion People, 327 ScI. 812, 812-15 (2010).

42. See, e.g., World Trade Organization, Declaration on the TRIPS Agreement and Public Health, WT/MIN(01)/DEC/2 (Nov. 20, 2001) (adopted Nov. 14, 2001), available at http:/www.wto.org/english/thewto_e/minist_e/min01_e/ mindecl trips e.htm.

43. Chidi Oguamanam, Agro-Biodiversity and Food Security: Biotechnology and Traditional Agricultural Practices at the Periphery of International Intellectual Property Regime Complex, 2007 Mich. ST. L. REV. 215, 244-45 (2007); see also Keith Aoki, "Free Seeds, Not Free Beer": Participatory Plant Breeding, Open Source Seeds, and Acknowledging User Innovation in Agriculture, 77 FORDHAM L. REV. 2275, 2275 (2009) ("[T] he rise and expansion of intellectual property rights in plants and varieties during the twentieth century has significantly reduced the role of farmers in plant breeding, turning them into consumers providing labor to raise crops in which others hold the underlying intellectual property rights."). 
modified seed was not exhausted and that a new invention is made when new genetically modified seeds are planted and grown. ${ }^{44}$ This answer, while perhaps acceptable from a patent law perspective, may be inadequate from a human rights, international-development, or biodiversity perspective. The next Part turns to a discussion of the primary international agreements that address patent rights.

\section{TURNING TO INTERNATIONAL LAW}

Monsanto is a global corporation. Intellectual property law, although it is domestic law, is also international law. Neither the World Trade Organization Agreement on Trade-Related Aspects of Intellectual Property Rights (TRIPS) nor any of the international agreements discussed here are directly applicable to the dispute in Monsanto v. Bowman. However, harmonized intellectual property standards were developed at the international level and much of the resistance to intellectual property rights has been in international fora. ${ }^{45}$ Thus, international law, while not a source of controlling law, is relevant to the broader discussion of intellectual property rights and agricultural biotechnology products. This Part will discuss the international laws that protect patent rights as well as the regimes that one can draw on as a counter to patent law.

The Paris Convention for the Protection of Industrial Property (Paris Convention) is the earliest international agreement relating to patents. ${ }^{46}$ The Paris Convention specifies that the protection of industrial property includes patents, among other things. ${ }^{47}$ This agreement requires national treatment for parties to the agreement. It also establishes various other requirements, such as the right of the inventor to be named, the right of priority for patent filings in different countries, and the independence of patents in different countries. ${ }^{48}$ According to the Paris Convention, "industrial property" is to be understood in its broadest sense so that it is not limited to

44. See Bowman v. Monsanto Co., 133 S. Ct. 1761, 1766-67 (2013).

45. See Paris Convention for the Protection of Industrial Property, Mar. 20, 1883, 21 U.S.T. 1583 [hereinafter Paris Convention]; Agreement on Trade-Related Aspects of Intellectual Property Rights, Apr. 15, 1994, Marrakesh Agreement Establishing the World Trade Organization, Annex C, 1869 U.N.T.S. 299 [hereinafter TRIPS Agreement]; World Trade Organization, Ministerial Declaration of 14 November 2001, WT/MIN(01)/DEC/1, 41 I.L.M. 746, 748-49 (2002) [hereinafter Doha Declaration].

46. See Paris Convention, supra note 45, at 1585.

47. Id.

48. Id. at $1586,1589-90$. 
industry and commerce but also includes "agricultural and . . . natural products, for example, wines, grain, tobacco leaf, fruit, cattle, minerals, mineral waters, beer, flowers, and flour." 49 Thus, patents relating to agricultural products find support in the Paris Convention.

TRIPS builds on the Paris Convention..$^{50}$ TRIPS established a minimum twenty-year term of protection for patents in all World Trade Organization (WTO) member countries. ${ }^{51}$ The TRIPS obligations apply to governments and not to private individuals. However, the TRIPS Agreement has been adopted by WTO member states, and the provisions have been implemented into national law. ${ }^{52}$ Thus, the national laws of WTO members, like the United States and Canada, should be consistent with the TRIPS Agreement. ${ }^{53}$

Article 27 of TRIPS addresses patentable subject matter. ${ }^{54}$ TRIPS Article 27.1 requires patent protection to be available for all fields of technology. ${ }^{55}$ Thus, subject to exceptions, WTO members cannot categorically exclude agricultural biotechnology products, or even more specifically, seeds, from patent protection. The language of TRIPS appears to be stronger than that of the Paris Convention, which specifically acknowledges agricultural patents but does not mandate patent protection for all fields of technology.

Importantly, however, the obligation in TRIPS that patents must be available for all fields of technology is subject to two

49. Id. at 1585 .

50. TRIPS incorporates parts of the Paris Convention and provides that nothing in TRIPS shall derogate from rights under the Paris Convention. See TRIPS Agreement, supra note 45, at 301.

51. See id. at 314. Article 33 states, "[t]he term of protection available shall not end before the expiration of a period of twenty years counted from the filing date." Id.

52. Marrakesh Agreement Establishing the World Trade Organization, Apr. 15, 1994, 1867 U.N.T.S. 154, 155 ("The agreements and associated legal instruments included in Annexes 1, 2 and 3 (hereinafter referred to as 'Multilateral Trade Agreements') are integral parts of this Agreement, binding on all Members.").

53. See TRIPS Agreement, supra note 45, at 301 ("Members shall give effect to the provisions of this Agreement. Members may, but shall not be obliged to, implement in their law more extensive protection than is required by this Agreement, provided that such protection does not contravene the provisions of this Agreement. Members shall be free to determine the appropriate method of implementing the provisions of this Agreement within their own legal system and practice.").

54. Id. at 311 .

55. Id. ("Subject to the provisions of paragraphs 2 and 3, patents shall be available for any inventions, whether products or processes, in all fields of technology, provided that they are new, involve an inventive step and are capable of industrial application."). 
specific exceptions. ${ }^{56}$ First, pursuant to Article 27.2 of TRIPS, WTO members can exclude inventions where it is necessary to do so in order to protect public order or morality. This provision allows exclusions to patent protection to "protect human, animal or plant life or health or to avoid serious prejudice to the environment." 57 Secondly, under Article 27.3, WTO members can exclude diagnostic and surgical methods for the treatment of humans and animals, and pursuant to Article 27.3(b), "plants and animals other than microorganisms, and essentially biological processes for the production of plants or animals other than non-biological and microbiological processes." ${ }^{958}$ Article 27.3(b) also requires that WTO members protect plant varieties through patent law or a sui generis regime.

Thus, Article 27.3(b) of TRIPS provides some flexibility for WTO member nations to exclude plants, and possibly biological material relating to plants, from patentability. This provision has been the subject of much discussion, particularly with respect to traditional knowledge and biodiversity. The TRIPS Agreement required a review of Article 27.3(b), which deals with patentability or non-patentability of plant and animal inventions, and the protection of plant varieties. ${ }^{59}$ In addition, the public order and morality clause, for instance, reflects an acknowledgement within TRIPS that there may be legitimate reasons outside of patent law for refusing to patent certain kinds of inventions. ${ }^{60}$

In addition to TRIPS Article 27, the Doha Declaration played an important role in shaping the conversation regarding intellectual property and biodiversity at the WTO ${ }^{61}$ The Declaration directed the Council for TRIPS to study the relationship between TRIPS, the Convention on Biological Diversity (CBD), and the protection of traditional knowledge and folklore. ${ }^{62}$ The Council's work on these

56. Id.

57. Id.

58. Id. at 312 .

59. Id. The final sentence reads, "[t]he provisions of this subparagraph shall be reviewed four years after the date of entry into force of the WTO Agreement." Id.

60. It may be very difficult for WTO Members to rely on this provision as a basis for opting out of their TRIPS obligations. Public order and morality are nebulous concepts, but more importantly, member states would have to demonstrate necessity.

61. Doha Declaration, supra note 45.

62. Paragraph 19 of the Doha Declaration states:

We instruct the Council for TRIPS, in pursuing its work programme including under the review of Article 27.3(b), the review of the implementation of the TRIPS Agreement under Article 71.1 and the work 
topics was to be guided by the objectives and principles of TRIPS, which are found in Articles 7 and 8, respectively, and to take development issues fully into account. The 2006 WTO report that was generated as a result concluded that TRIPS and CBD are not inconsistent but that further study is required. ${ }^{63}$ Thus, while the Doha Declaration reflects a desire to protect the interests of both producers and users of intellectual property-protected goods related to agricultural products, the Article 27.3(b) review does not help to answer the question of the exhaustion of self-replicating technologies. This is because the focus has been on disclosure of genetic resources, protection of traditional knowledge, and benefit sharing. ${ }^{64}$

Another TRIPS provision that one might draw on is TRIPS Article 7, which speaks to the goal of intellectual property protection as promoting innovation and technology transfer "to the mutual advantage of producers and users of technological knowledge and in a manner conducive to social and economic welfare, and to a balance of rights and obligations." ${ }^{65}$ Article 8 of TRIPS gives WTO members the flexibility to take measures to protect public health and nutrition, provided that the measures are consistent with the TRIPS obligations. ${ }^{66}$ There was no legitimate health or nutrition purpose raised by the plaintiffs in either the Bowman or Schmeiser cases, so Article 8 would not have any bearing on the analysis of those cases. Health concerns related to the genetically modified Monsanto seed

foreseen pursuant to paragraph 12 of this declaration, to examine, inter alia, the relationship between the TRIPS Agreement and the Convention on Biological Diversity, the protection of traditional knowledge and folklore, and other relevant new developments raised by members pursuant to Article 71.1. In undertaking this work, the TRIPS Council shall be guided by the objectives and principles set out in Articles 7 and 8 of the TRIPS Agreement and shall take fully into account the development dimension.

Id. at 749 .

63. See Council for Trade-Related Aspects of Intellectual Property Rights, Note by the Secretariat: The Relationship Between the TRIPS Agreement and the Convention on Biological Diversity: Summary of Issues Raised and Points Made, IP/C/W368/Rev.1 (Feb. 8, 2006).

64. Id. at 5.

65. See TRIPS Agreement, supra note 45, at 303.

66. TRIPS, Article 8.1 states, "[m]embers may, in formulating or amending their laws and regulations, adopt measures necessary to protect public health and nutrition, and to promote the public interest in sectors of vital importance to their socio-economic and technological development, provided that such measures are consistent with the provisions of this Agreement." Id. 
and the Roundup Ready pesticide could, however, be raised by farmers who wanted to avoid the Monsanto product but had their crops inadvertently contaminated. This was not the case in either Bowman or Schmeiser.

Article 7, however, is relevant insofar as it indicates that intellectual property protection and enforcement should be to the advantage of users as well as producers. As a user, Bowman argued that the patent rights in the seed had been exhausted after the first sale. ${ }^{67}$ Article 6 of TRIPS explicitly recognizes the lack of international agreement on the question of exhaustion of intellectual property rights. ${ }^{6}$ While Article 6 of TRIPS specifically refers to dispute settlement between countries, the principle that the provisions of the Agreement should not be used to address the question of exhaustion of rights is nonetheless pertinent. It was possible to reach global agreement on many things, including patentable subject matter and patent term, but there was no agreement on exhaustion, so international law is not helpful in this regard..$^{69}$

Intellectual property protection is subject to exceptions. The question TRIPS cannot answer is where society should draw the line between protection that will stimulate innovation and the level of protection that will stifle innovation or cause other harms. TRIPS Article 30 recognizes exceptions to patent protection. However, the exceptions must not "unreasonably conflict with a normal exploitation of the patent" or "unreasonably prejudice the legitimate interests of the patent owner, taking account of the legitimate interests of third parties." $" 70$

The TRIPS Agreement offers no clear solution. International intellectual property agreements alone will not provide solutions to the difficult questions regarding gene technologies and self-

67. Bowman v. Monsanto Co., 133 S. Ct. 1761, 1765 (2013).

68. See TRIPS Agreement, supra note 45, at 303. Article 6 states, "[f]or the purposes of dispute settlement under this Agreement, subject to the provisions of Articles 3 and 4 nothing in this Agreement shall be used to address the issue of the exhaustion of intellectual property rights." Id.

69. This provision would be primarily about the applicability of national, regional, or international exhaustion rather than determining when a particular test for exhaustion has been met.

70. See TRIPS Agreement, supra note 45, at 312-13 ("Members may provide limited exceptions to the exclusive rights conferred by a patent, provided that such exceptions do not unreasonably conflict with a normal exploitation of the patent and do not unreasonably prejudice the legitimate interests of the patent owner, taking account of the legitimate interests of third parties."). 
replicating inventions. This is because, as Chidi Oguamanam argues, TRIPS is driven by a "commodity logic," which aims to maximize profits for intellectual property producers. ${ }^{71}$ Oguamanam contends:

This vision of intellectual property rights is mainly championed by Western countries. It stands in conflict with a core objective of intellectual property in terms of fostering innovation . . . and most important . . . it undermines an alternative vision of intellectual property, one that supports the role of intellectual property in promoting public claims to knowledge and other issues bordering on social justice or public interest. ${ }^{72}$

Critics of strong intellectual property rights for agricultural products express concern for agro-biodiversity as well as the increased risk of food insecurity, particularly for developing countries. ${ }^{73}$ Rural communities in particular may be impacted because most of the world's poor live in rural areas. ${ }^{74}$ Agrobiodiversity, which is related to the promotion of food security, is about sustaining the diversity of the agricultural ecosystem..$^{75}$ Thus, patenting seeds and other food-related technologies can present human rights concerns.

The next section of this Article will discuss regimes outside of intellectual property law that have different goals from TRIPS and that provide alternative frameworks for analyzing the challenges raised by intellectual property rights in agricultural biotechnologies. Professor Oguamanam speaks of regimes and counter-regimes. ${ }^{76}$ These include international human rights law, the Convention on Biological Diversity, and the International Treaty on Plant Genetic Resources.

71. Chidi Oguamanam, Regime Tension in the Intellectual Property Rights Arena: Farmer's Rights and Post-TRIPS Counter Regime Trends, 29 DALHOUSIE L.J. 413, 424 (2006) (quoting James Thuo Gathii, Rights, Patents, Markets and the Global AIDS Pandemic, 14 FLA. J. INT'L L. 261, 309 (2002)).

72. Id.

73. See Oguamanam, supra note 43, at 219.

74. "The United Nations Millennium Development Project's Task Force on Hunger has shown that 80 per cent of the world's hungry live in rural areas." Human Rights Council, Requests Addressed to the Advisory Committee Stemming from Human Rights Council Resolutions: Right to Food, A/HRC/AC/3/CRP.5 (Aug. 4, 2009).

75. See Oguamanam, supra note 43 , at 220.

76. See Oguamanam, supra note 71 , at 417. 


\section{A. Counter-Regimes}

Human rights law can serve as a counter-regime to intellectual property law. The Universal Declaration of Human Rights (UDHR) is the principal international source for human rights law. The UDHR, together with the International Covenant on Civil and Political Rights (ICCPR) and the International Covenant on Economic, Social, and Cultural Rights (ICESCR), comprise the International Bill of Human Rights. ${ }^{77}$ The ICESCR is not legally binding on the United States because it has not been ratified. ${ }^{78}$ However, the United States is a signatory to the ICESCR, and it has ratified the ICCPR. ${ }^{79}$

Human rights arguments could be based, for instance, on the right to food or the right to health. Article 25(1) of the UDHR provides that "[e]veryone has the right to a standard of living adequate for the health and well-being of himself and of his family, including food, clothing, housing and medical care." ${ }^{80}$ Article 11(1) of the ICESCR similarly provides that everyone has the right "to an adequate standard of living for himself and his family, including adequate food, clothing and housing, and to the continuous improvement of living conditions." ${ }^{" 81}$ Article 11(1) goes on to state that the parties to the agreement will take steps to ensure that this right is realized. ${ }^{82}$ Under Article 11(2), everyone has a fundamental

77. Office of the High Comm'r for Human Rights, Fact Sheet No.2 (Rev.1), THE InTERnATIONAL BILL OF HumAN Rights, available at http://www.ohchr.org/Documents/Publications/FactSheet2Rev.1en.pdf ("The International Bill of Human Rights consists of the Universal Declaration of Human Rights, the International Covenant on Economic, Social and Cultural Rights, and the International Covenant on Civil and Political Rights and its two Optional Protocols.").

78. The United States became a signatory to the ICESCR in 1977, but unlike the International Covenant on Civil and Political Rights, the United States has not ratified the ICESCR. See G.A. Res. 2200A (XXI), U.N. Doc. A/6316 (Dec. 16, 1966) [hereinafter ICESCR], available at http://www.ohchr.org/EN/ ProfessionalInterest/Pages/CESCR.aspx.

79. Id.

80. Universal Declaration of Human Rights art. 25(1), G.A. Res. 217A (III), U.N. Doc. A/RES/ 217 (III) (Dec. 10, 1948) [hereinafter UDHR].

81. ICESCR, supra note 78, at art. 11(1).

82. Id. 
right to be free from hunger. ${ }^{83}$ The right to food encompasses the availability of food as well as the economic accessibility of food ${ }^{84}$

Biotechnological innovation is not necessarily inconsistent with the right to adequate food and could, in some instances, support the availability of adequate food supplies. ${ }^{85}$ However, should farmers be limited in their ability to produce crops because of patent rights, then the patent protection for the agricultural biotechnology could be inconsistent with the right to food. For instance, one of the interveners pointed out that Monsanto controls more than $85 \%$ of all soybean, corn, cotton, sugar beets, and canola grown in the United States. ${ }^{86}$

The right to health is found in Article 25 of the $\mathrm{UDHR}^{87}$ and Article 12 of the ICESCR, which recognizes "the right of everyone to the enjoyment of the highest attainable standard of physical and mental health." $" 88$ The right to health under human rights law is broader than the right to health as defined by the World Health Organization. Among other things, the right to health encompasses the right to food. ${ }^{89}$ In addition, some critics have health concerns

83. Id. at art. 11(2).

84. Comm. on Econ., Soc. \& Cultural Rights, Gen. Comment No. 12 on its 20th Sess., U.N. Doc. E/C.12/1999/5 (May 12, 1999).

85. If the technology makes more food more easily available in terms of quantity and cost, then it could be promoting the human right to food.

86. First Amended Complaint at 35, Organic Seed Growers \& Trade Ass'n v. Monsanto Co., 851 F. Supp. 2 d 544 (S.D.N.Y. 2012) (No. 11 Civ. 2163(NRB)) ("Monsanto dominates the market for transgenic seeds and traits. Monsanto currently holds the largest percentage of the global proprietary seed market of any company. In the United States, Monsanto's control of the seed market is so high that over $85-90 \%$ of all soybeans, corn, cotton, sugar beets and canola grown in the United States contains Monsanto's patented genes.").

87. UDHR Article 25 states:

(1) Everyone has the right to a standard of living adequate for the health and well-being of himself and of his family, including food, clothing, housing and medical care and necessary social services, and the right to security in the event of unemployment, sickness, disability, widowhood, old age or other lack of livelihood in circumstances beyond his control. (2) Motherhood and childhood are entitled to special care and assistance. All children, whether born in or out of wedlock, shall enjoy the same social protection.

UDHR, supra note 80, at art. 25.

88. See ICESCR, supra note 78, at art. 12.

89. Comm. on Econ., Soc. \& Cultural Rights, Gen. Comment No. 14 on its 22d Sess., Apr. 25-May 12, 2000, ๆ 3, U.N. Doc. E/C.12/2000/4 (Aug. 11, 2000) ("The right to health is closely related to and dependent upon the realization of other human rights, as contained in the International Bill of Rights, including the rights to food, housing, work, education, human dignity, life, non-discrimination, equality, 
regarding genetically modified seeds and the pesticide application that is part of the Monsanto process. ${ }^{90}$

Another counter-regime can be found in the CBD. The primary goal of the CBD is the protection of biodiversity. ${ }^{91}$ It also aims to ensure prior informed consent for access to genetic resources and benefit sharing for products derived from genetic resources and technology transfer. ${ }^{92}$ It intersects with intellectual property law in various ways. For instance, the CBD explicitly mentions and defines biotechnology, ${ }^{93}$ and encourages technology transfer while recognizing that these technologies may be protected by patents or other intellectual property laws. ${ }^{94}$

The CBD also promotes protection for the practices of traditional and local communities. ${ }^{95}$ These CBD provisions have been the subject of study and discussion at the WTO and the World Intellectual Property Organization. ${ }^{96}$ Article $8(\mathrm{j})$ of the CBD speaks of preserving knowledge, innovations, and practices of indigenous and local communities that embody traditional lifestyles and promote biological diversity. ${ }^{97}$ In Article 16, the parties to the CBD undertake

the prohibition against torture, privacy, access to information, and the freedoms of association, assembly and movement. These and other rights and freedoms address integral components of the right to health.").

90. First Amended Complaint at 39, Organic Seed Growers, 851 F. Supp. 2d 544 (No. 11 Civ. 2163(NRB)).

91. See Convention on Biological Diversity art. 1, June 5, 1992, 1760 U.N.T.S. 79 [hereinafter CBD].

92. CBD Article 1 states:

The objectives of this Convention, to be pursued in accordance with its relevant provisions, are the conservation of biological diversity, the sustainable use of its components and the fair and equitable sharing of the benefits arising out of the utilization of genetic resources, including by appropriate access to genetic resources and by appropriate transfer of relevant technologies, taking into account all rights over those resources and to technologies, and by appropriate funding.

Id.

93. CBD Article 2 defines "[b]iotechnology" to mean "any technological application that uses biological systems, living organisms, or derivatives thereof, to make or modify products or processes for specific use." Id. at art. 2. The word " "technology"" is also defined to include biotechnology. Id.

94. Id. at art. 16.

95. Id. at art. 8(j).

96. See generally Intergovernmental Comm. on Intellectual Prop. \& Genetic Res., Traditional Knowledge and Folklore, Disclosure of Origin or Source of Genetic Resources and Associated Traditional Knowledge in Patent Applications, Eighth Sess., June 6-10, 2005, WIPO/GRTKF/IC/8/11 (May 17, 2005).

97. See CBD, supra note 91 , at art. 8(j). 
to facilitate technology transfer, including biotechnology, while respecting intellectual property rights. ${ }^{98}$

The Food and Agriculture Organization (FAO) is an additional resource for those seeking to protect the interests of farmers. The International Treaty on Plant Genetic Resources for Food and Agriculture (ITPGR), which as developed at the FAO, has as its objective the sustainable use of genetic resources and "fair and equitable sharing of the benefits arising out of their use." 99 Article 9 of the ITPGR recognizes Farmer's Rights. ${ }^{100}$ While the ITPGR makes it clear that farmers have the right to save, use, and exchange their seed, it is equally clear that this is subject to national law and only "as appropriate." 101 Thus, while this treaty recognizes Farmer's Rights, the protection is relatively weak. Whatever rights farmers have under the ITPGR are subject to national law, and even then, farmers have only those rights deemed "appropriate" by states.

In contemplating whether Monsanto should be limited in its ability to control self-replicating genetically modified seeds, we should be guided not only by patent law, but also by principles from international agreements that are concerned with human welfare and human progress. These counter-regimes found in human rights agreements, the CBD, and the ITPGR can serve as persuasive counterweights to the economic focus of the agreements that protect intellectual property. The challenge, from a legal perspective, is that the existence of these counter-regimes does not alter any domestic or international intellectual property regime. In other words, none of these human rights or agricultural agreements has sufficient legal effect to constrain patent law. This is largely due to the fact that powerful countries like the United States have either not ratified the agreements, or these agreements have taken the form of declarations or guidelines.

Intellectual property laws are supposed to produce some social benefit. ${ }^{102}$ Some part of the solution may lay in recasting the role of

98. Id. at art. 16 .

99. Food \& Agric. Org. of the United Nations, International Treaty on Plant Genetic Resources for Food AND Agriculture art. 1.1 (2009) [hereinafter ITPGR], available at ftp://ftp.fao.org/docrep/fao/011/i0510e/i0510e.pdf.

100. Id. at art. 9 .

101. Id. at art. 9.3 ("Nothing in this Article shall be interpreted to limit any rights that farmers have to save, use, exchange and sell farm-saved seed/propagating material, subject to national law and as appropriate.").

102. Christopher May, The Global Political Economy of Intellectual Property Rights: The New Enclosures 5 (2d ed. 2010) ("The argument that there are social benefits to be gained from the development and 
intellectual property in promoting "progress" as human progress rather than primarily economic progress. ${ }^{103}$ Promoting human progress is no more nebulous than "promot[ing] the Progress of Science and [the] useful Arts," to draw on language from the United States Constitution. ${ }^{104}$

Human progress can take into account economic progress, scientific and artistic progress, and the human development indices that are used by the United Nations. There are indices to measure the health of the population, literacy, educational attainment, life expectancy, and a variety of factors that are indicative of quality of life. The Human Development Index recognizes that economic progress alone is not an adequate measure of progress. ${ }^{105}$ There is no reason why promoting scientific progress cannot be done concomitantly with the promotion of human progress. Human development is multifaceted, and includes progress in terms of health, education, and economic wealth. Promoting progress in this broader sense will require intellectual property law to draw on the various counter-regimes for guidance.

\section{CONCLUSION}

In the United States, domestic courts generally do not apply international law. ${ }^{106}$ However, intellectual property law is an area of law that is very much internationalized. Minimum intellectual

dissemination of 'new' knowledge and information underpins the legal construction of IPRs. To this end, all IPRs encompass a balance between private rights for reward and public needs for the (unconstrained) availability of important knowledge and information.").

103. Alina $\mathrm{Ng}$ has argued that there are other ways to conceive of "progress." See Alina NG, Copyright LaW and the Progress of SCIENCE AND the USEFUL ARTS 123 (2011) ("We have unwittingly permitted economics rather than ethics to be the governing influence upon the behaviour of those creating, producing, and using literary and artistic work within the copyright system. In many ways, the progress of science and the useful arts works on a very different plane from the one we have constructed through our laws.").

104. U.S. CONST. art. I, § 8, cl. 8.

105. Human Development Index (HDI), UN Dev. Programme, http://hdr.undp.org/en/content/human-development-index-hdi (last visited Apr. 13, 2015) ("The [Human Development Index] was created to emphasize that people and their capabilities should be the ultimate criteria for assessing the development of a country, not economic growth alone.”).

106. This holds true even though there is a constitutional provision that states that all treaties entered into by the United States "shall be the supreme Law of the Land." U.S. CONST. art. VI, cl. 2. 
property standards were established globally, and much of the resistance to intellectual property standards is taking place at the international level. Furthermore, the challenges posed by the patenting of live, self-replicating technologies are not limited to a single nation. Monsanto is a global corporation that transacts business across borders.

The primary multilateral intellectual property agreement, TRIPS, offers some flexibility to nations. However, TRIPS by itself cannot provide solutions to the moral and ethical challenges some scholars have raised. Human rights regimes and agricultural treaties are helpful insofar as their goals are distinct from the "commodityoriented" focus of TRIPS. Yet, these agreements do not have sufficient legal force to counteract patent law where necessary. Nonetheless, we might draw on agreements like the Convention on Biological Diversity, the International Treaty on Plant Genetic Resources for Food and Agriculture, and human rights instruments for guidance in shaping intellectual property law to give greater weight, in some instances, to interests that may be contrary to those of the patent owner.

Guided by the principles from these counter-regimes, patent law can be developed so that it promotes progress, more broadly defined, as well as innovation. Economic progress is essential, but innovation is also about social progress and human development. ${ }^{107}$ However, intellectual property laws that are interpreted and applied based predominantly on an economic model of progress will continue to leave us with unsatisfactory answers to difficult questions.

107. Human development or human progress can be measured by reference to indices such as the United Nations Human Development Index. See supra note 105. 
